\title{
Melatonin Inhibits Oxidized Low Density Lipoprotein Induced Proliferation and Migration of Vascular Smooth Muscle Cells and its Mechanism
}

\author{
YANG TANG ${ }^{1}, \mathrm{CHUAN} \mathrm{LIU}, \mathrm{HUALI}$ KANG, MENGYANG DENG AND JUN JIN* \\ Department of Cardiology, Xinqiao Hospital, Army Medical University (Third Military Medical University), Chongqing 400038, \\ ${ }^{1}$ Department of Cardiology, People's Hospital of Chongqing Banan District, Chongqing 401320, China
}

Tang et al.: Effect and Molecular Mechanism of Melatonin on the Vascular Smooth Muscle Cells Proliferation

The effect and molecular mechanism of melatonin on the vascular smooth muscle cells proliferation and vascular smooth muscle cells migration induced by oxidized low density lipoprotein was explored in this paper. The first scheme: induce vascular smooth muscle cells with series of oxidized low density lipoprotein concentrations for $48 \mathrm{~h}(0 \mu \mathrm{g} / \mathrm{ml}, 10 \mu \mathrm{g} / \mathrm{ml}, 20 \mu \mathrm{g} / \mathrm{ml}, 50 \mu \mathrm{g} / \mathrm{ml}$ and $100 \mu \mathrm{g} / \mathrm{ml})$. The second scheme: $50 \mu \mathrm{g} / \mathrm{ml}$ oxidized low density lipoprotein was used to induce vascular smooth muscle cells $\mathrm{s}$ for $0 \mathrm{~h}, 6 \mathrm{~h}, 12 \mathrm{~h}, 24 \mathrm{~h}$ and $48 \mathrm{~h}$. The third option: first induce vascular smooth muscle cells with $50 \mu \mathrm{g} / \mathrm{ml}$ oxidized low density lipoprotein for $24 \mathrm{~h}$, then treat vascular smooth muscle cells with series of melatonin concentrations for $48 \mathrm{~h}(1 \mathrm{nmol} / \mathrm{l}, 1 \mu \mathrm{mol} / \mathrm{l}, 0.1 \mathrm{mmol} / \mathrm{l}, 1 \mathrm{mmol} / \mathrm{l})$. Cell Counting Kit-8 method was used to detect cell proliferation. Cells were randomly divided into blank control group, melatonin group $(0.1 \mathrm{mmol} / \mathrm{l}$ melatonin treatment vascular smooth muscle cells $48 \mathrm{~h})$, oxidized low density lipoprotein group (vascular smooth muscle cells were induced by $50 \mu \mathrm{g} / \mathrm{ml}$ oxidized low density lipoprotein for $24 \mathrm{~h}$ ), oxidized low density lipoprotein+melatonin group $(50 \mu \mathrm{g} / \mathrm{ml}$ of oxidized low density lipoprotein induced vascular smooth muscle cells for $24 \mathrm{~h}$ and then treated vascular smooth muscle cells s with $0.1 \mathrm{mmol} / \mathrm{l}$ of melatonin for $48 \mathrm{~h}$ ). After relative treatment, cell cycle was detected by flow cytometry and cell migration was detected by scratch test. Proliferating cell nuclear antigen, alpha smooth muscle actin, cyclin A and extracellular regulatory protein kinase were detected by immunofluorescence staining and Western blot 1/2 (extracellular regulatory protein kinase 1/2) signal pathway related protein expression. Compared with the blank control group, vascular smooth muscle cells s treated with $50 \mu \mathrm{g} / \mathrm{ml}$ oxidized low density lipoprotein could significantly induce cell proliferation. After $24 \mathrm{~h}$ of induction by oxidized low density lipoprotein $(50 \mu \mathrm{g} / \mathrm{ml})$, the number of cells in S phase and G1 phase was decreased significantly and the number of cells in G2 phase was increased significantly. Cell migration was promoted and proliferating cell nuclear antigen, cyclin A, Cyclina, p-extracellular regulatory protein kinase 1/2 protein expression was up-regulated, down regulating the p-p21 protein level. The difference was statistically significant $(\mathrm{p}<0.01)$. The melatonin with series concentrations $(1 \mathrm{nmol} / \mathrm{l}, 1 \mu \mathrm{mol} / \mathrm{l}, 0.1 \mathrm{mmol} / \mathrm{l}$ and $1 \mu \mathrm{mmol} / \mathrm{l}) \mathrm{could}$ inhibit the proliferation of vascular smooth muscle cells induced by oxidized low density lipoprotein to varying degrees. After vascular smooth muscle cells treatment with oxidized low density lipoprotein $(50 \mu \mathrm{g} / \mathrm{ml})$ for $24 \mathrm{~h}$ and melatonin $(0.1 \mathrm{mmol} / \mathrm{l})$ for $48 \mathrm{~h}$, the cells in $\mathrm{G1}$ and $\mathrm{S}$ phase increased significantly, the cells in G2 phase decreased significantly, the cell migration was inhibited, which were compared with oxidized low density lipoprotein oxidized low density lipoprotein group. The expression of proliferating cell nuclear antigen, cyclin A, Cyclina, p-extracellular regulatory protein kinase 1/2 protein was decreased and the expression of $\mathbf{p}$-p21 protein was up-regulated, the difference was statistically significant $(\mathrm{p}<0.01)$. Melatonin can significantly inhibit the proliferation and migration of vascular smooth muscle cells induced by oxidized low density lipoprotein and its mechanism may be related to activating p21 and blocking extracellular regulatory protein kinase 1/2 signaling pathway.

Key words: Vascular smooth muscle cells, melatonin, oxidized low density lipoprotein, proliferation, migration

Atherosclerosis (AS), the kind of chronic inflammatory disease, was the common basis of many cardiovascular and cerebrovascular diseases, which was characterized

This is an open access article distributed under the terms of the Creative Commons Attribution-NonCommercial-ShareAlike 3.0 License, which allows others to remix, tweak, and build upon the work non-commercially, as long as the author is credited and the new creations are licensed under the identical terms 
by the accumulation of inflammatory cells and cholesterol in the arterial wall and involved the whole vascular disease $\mathrm{e}^{[1]}$. In recent years, the mortality caused by as was increasing year by year, serious threatening human health ${ }^{[2]}$. Over proliferation and abnormal migration of vascular smooth muscle cells (VSMCs) were the key links in the occurrence and development of $\mathrm{AS}^{[3,4]}$. Maintaining the dynamic balance between proliferation and apoptosis of VSMCs and reducing the abnormal migration of VSMCs were essential for maintaining the normal physiological function of blood vessels, which were also potential therapeutic targets of $\mathrm{AS}^{[5]}$. Melatonin (MEL), the indole hormone secreted by pineal gland, had the functions of anti-inflammatory, anti-oxidation and regulating cardiovascular system. Previous studies also found that MEL can act on vascular VSMCs and regulate vascular VSMCs, but its specific regulatory mechanism was not very clear at present, which may be related to its inhibition of VSMCs over proliferation $^{[6,7]}$. Oxidized low density lipoprotein (ox-LDL) was the key factor in atherosclerosis and vascular calcification, which can promote osteogenic differentiation and calcification of vascular smooth muscle cells. The effects on the proliferation, cell cycle and migration of VSMCs induced by ox-LDL with different concentrations of MEL were explored in this paper. The changes of cell cycle and proliferation related proteins were detected to elucidate the molecular mechanism of MEL regulating vascular VSMCs, so as to provide new ideas for anti-AS therapy.

\section{MATERIALS AND METHODS}

\section{Main materials and reagents:}

Human vascular smooth muscle cells (VSMCs) were purchased from Shanghai cell bank of Chinese Academy of Sciences. ox LDL, MEL, fetal bovine serum and trypsin were purchased from sigma. DMEM media was purchased from Thermo Fisher Scientific in the United States. Cell Counting Kit-8 (CCK-8) and PI kit were purchased from Promega, USA. ECL, RIPA and BCA protein detection kits were purchased from Shanghai biyuntian Institute of biology. Rat anti-Proliferating cell nuclear antigen (PCNA), Rabbit anti-alpha smooth muscle actin ( $\alpha$-SMA), Rabbit anti Cyclina, rabbit p21, rabbit p-p21 and rat anti $\beta$-actin antibodies were purchased from Abcam Company in the UK. Rabbit anti ERK 1/2 and rabbit anti-p-ERK 1/2 antibodies were purchased from Cell Signaling Technology (CST).

Tetramethylrhodamine (TRITC) labeled Goat anti-rabbit Immunoglobulin $\mathrm{G}$ (IgG), Fluorescein isothiocyanate (FITC) labeled Goat anti-mouse IgG and Horseradish peroxidase (HRP) labeled Goat antirabbit IgG were purchased from Santa Cruz Company of the United States.

\section{Cell culture:}

VSMCs were cultured in Dulbecco's Modified Eagle's medium (DMEM) containing $10 \%$ fetal bovine serum and $1 \%$ penicillin/streptomycin in $37^{\circ}$ and $5 \% \mathrm{CO}_{2}$ cell incubator. The medium was changed every $2 \mathrm{~d}$. After the cells grew up to the bottom of the culture bottle, the cells were washed with Phosphate Buffered Saline (PBS) buffer, digested with $0.25 \%$ trypsin and sub cultured.

\section{Cell grouping and treatment:}

VSMCs were induced by ox-LDL with final concentration for $48 \mathrm{~h}(0 \mu \mathrm{g} / \mathrm{ml}, 10 \mu \mathrm{g} / \mathrm{ml}, 20 \mu \mathrm{g} / \mathrm{ml}$, $50 \mu \mathrm{g} / \mathrm{ml}$ and $100 \mu \mathrm{g} / \mathrm{ml}$ ) and the cell proliferation of each group was detected; VSMCs were induced by $50 \mu \mathrm{g} / \mathrm{ml}$ ox-LDL for $0 \mathrm{~h}, 6 \mathrm{~h}, 12 \mathrm{~h}, 24 \mathrm{~h}, 48 \mathrm{~h}$ and cell proliferation was detected; On the basis of inducing VSMCs with $50 \mu \mathrm{g} / \mathrm{ml}$ ox-LDL for $24 \mathrm{~h}$, VSMCs were treated with MEL with final concentration for $48 \mathrm{~h}$ ( $1 \mathrm{nmol} / \mathrm{l}, 1 \mu \mathrm{mol} / \mathrm{l}, 0.1 \mathrm{mmol} / \mathrm{l}$ and $1 \mathrm{mmol} / \mathrm{l}$ ) to detect the cell proliferation of each group; The VSMCs were treated with ox-LDL and MEL and the subsequent experiments were carried out. The specific groups included: blank control group (VSMCs were cultured without any treatment), MEL group (0.1 mmol/1MEL treatedVSMCs for $48 \mathrm{~h})$, ox-LDLgroup $(50 \mu \mathrm{g} / \mathrm{ml}$ ox-LDL was used to induce VSMCs for $24 \mathrm{~h}$ ), ox-LDL+MEL group $(50 \mu \mathrm{g} / \mathrm{ml}$ ox-LDL was used to induce VSMCs for $24 \mathrm{~h}$, then $0.1 \mathrm{mmol} / 1 \mathrm{MEL}$ was used to treat VSMCs for $48 \mathrm{~h}$ ).

\section{CCK-8:}

The well-grown VSMCs were seeded on 96-well cell culture plates at $1 \times 10^{4} /$ well and cultured overnight in a cell incubator at $37^{\circ}$ and $5 \% \mathrm{CO}_{2}$, carried out different treatments according to 1.3 , and set 3 multiple holes for each hole. Next, $10 \mu \mathrm{l}$ of CCK-8 solution was added in to each well, mixed well and placed in the cell incubator to continue culturing for $1 \mathrm{~h}$. After culturing, the absorbance value of each well was measured by the enzyme-linked immunoassay detector at $450 \mathrm{~nm}$.

\section{Flow cytometry:}

Well-grown VSMCs was inoculated in 6-well cell culture plates and performed experimental grouping 
and drug intervention according to $1.3^{[4]}$. After the experiment, collecting the cells, washing the cells with PBS, the cells with pre-chilled $75 \%$ ethanol was resuspended, fixing them at $-20^{\circ}$ for $24 \mathrm{~h}$, discarding the ethanol, washing and resuspending the cells with PBS again. $450 \mu \mathrm{l}$ of cell suspension in each group was taken, adding $2 \mu 1$ RNase and incubated at $37^{\circ}$ for $10 \mathrm{~min}$, then adding $500 \mu \mathrm{l}$ of propidium iodide and incubated at $37^{\circ}$ in the dark for $30 \mathrm{~min}$. The cell cycle distribution was detected by flow cytometry.

\section{Cell scratch test:}

Drawing a horizontal line evenly every $0.5 \mathrm{~cm}$ behind the 6-well culture plate, treated groups of VSMCs were added into the culture plate at $5 \times 10^{5} /$ well. On the $2^{\text {nd }} \mathrm{d}$, using a pipette tip to scratch along the ruler perpendicular to the horizontal line behind the cell culture well, the cells were washed with PBS to remove the cells under the scratch. Then the serum-free DMEM medium was added and placed it in a $37^{\circ}, 5 \% \mathrm{CO}_{2}$ cell incubator to continue culturing, observing the migration distance after $48 \mathrm{~h}$ and taking pictures.

\section{Immunofluorescence staining:}

After the cell slides were processed, the slides were washed with PBS, fixed with $4 \%$ paraformaldehyde for $15 \mathrm{~min}$ and permeabilized with $0.2 \%$ Triton X-100 for $15 \mathrm{~min}$ at room temperature. Blocked with $5 \%$ fetal bovine serum for $1 \mathrm{~h}$ at room temperature and then mouse anti-PCNA (1:100) and rabbit anti$\alpha$-SMA (1:50) was added as primary antibodies to incubate at $4^{\circ}$ overnight. After washing with PBS the next day, TRITC-labeled goat anti-rabbit IgG (1:100) or FITC-labeled goat anti-mouse $\operatorname{IgG}(1: 100)$ were added as secondary antibodies, incubated in the dark room at room temperature for $1 \mathrm{~h}$, and washed with PBS. The nuclei were stained with 4',6-Diamidino2-phenylindole (DAPI) for $10 \mathrm{~min}$, washed with PBS again, then mounted, observed under the fluorescence microscope and acquired images.

\section{Western blot:}

After VSMCs were divided into groups according to the experiment in $1.3^{[4]}$ and drug intervention, the cells of each group were collected. The total protein of the cells was extracted by RIPA lysate, determined according to the steps of the BCA protein detection kit. The $10 \%$ sodium dodecyl sulphatepolyacrylamide gel electrophoresis (SDS-PAGE) gel was prepared and electrophoresed at $50 \mathrm{~V}$ constant voltages for $1.5 \mathrm{~h}$. After each band was clearly separated, the protein was separated by adjusted the voltage to $110 \mathrm{~V}$ for $1 \mathrm{~h}$. After separation, the adhesive was cut and the membrane was transferred for $4 \mathrm{~h}$ at constant current of $200 \mathrm{Ma}$. And $5 \%$ skimmed milk powder was sealed at room temperature for $2 \mathrm{~h}$. The mouse antiPCNA (1:2000), rabbit anti- $\alpha$-SMA (1:1000), rabbit anti-Cyclin A (1:1000), rabbit P21 (1:1000), rabbit p-P21 (1:1000), rabbit Anti-ERK 1/2 (1:1000), rabbit anti-p-ERK $1 / 2(1: 1000)$, mouse anti- $\beta$-actin $(1: 1000)$ antibody were added in to the culture medium. The protein was incubated overnight at $4^{\circ}$. And the next day, Goat anti-rabbit IgG antibody (1:5000) labeled with HRP was incubated at room temperature for $2 \mathrm{~h}$. The protein gray value was analyzed by Image Pro Plus 6.0.

\section{Statistical analysis:}

SPSS23.0 software was used for analysis. The experimental results were expressed as mean \pm standard deviation. T-test was used for comparison between the two groups and single factor analysis of variance was used for comparison between multiple groups. $\mathrm{p}<0.05$ was statistically significant.

\section{RESULTS AND DISCUSSION}

CCK-8 method cell viability measurement results show that compared with the blank control group, VSMCs treated with ox-LDL at 10,20 , and $50 \mu \mathrm{g} / \mathrm{ml}$ for $48 \mathrm{~h}$ can significantly promote cell proliferation $(p<0.01)$, shows that within a certain range $(0-50 \mu \mathrm{g} /$ $\mathrm{ml}$ ), ox-LDL promotes the proliferation of VSMCs in a concentration-dependent manner and $50 \mu \mathrm{g} / \mathrm{ml} \mathrm{Ox-}$ LDL had the most significant effect $(\mathrm{p}<0.01)$. As the oxLDL concentration continued to increase to $100 \mu \mathrm{g} / \mathrm{ml}$, the proliferation rate of VSMCs decreased significantly compared with the control group $(\mathrm{p}<0.01)$ (fig. 1A).

Next, As the VSMCs were treated with $50 \mu \mathrm{g} / \mathrm{ml}$ Ox-LDL for $6,12,24$, and $48 \mathrm{~h}$ (compared with the blank control group), ox-LDL promoted the proliferation of VSMCs in a time-dependent manner from 6 to $24 \mathrm{~h}$ and $50 \mu \mathrm{g} / \mathrm{ml}$ ox-LDL for $24 \mathrm{~h}$ had the most significant effect $(\mathrm{p}<0.01)$ (fig. 1B). Therefore, in the subsequent experiments, $50 \mu \mathrm{g} / \mathrm{ml}$ Ox-LDL was used to treat VSMCs for $24 \mathrm{~h}$ to establish an Ox-LDL induction model.

The results of CCK-8 cell viability assay showed that compared with the blank control group, the survival rate of VSMCs in Ox-LDL group $(50 \mu \mathrm{g} / \mathrm{mLOx}-\mathrm{LDL}$ treated VSMCs for $24 \mathrm{~h}$ ) was significantly improved $(\mathrm{p}<0.01)$. However, $1 \mathrm{nmol} / 1,1 \mu \mathrm{mol} / 1,0.1 \mathrm{mmol} / 1$ and $1 \mathrm{mmol} / \mathrm{l} \mathrm{MEL}$ can inhibit Vox proliferation induced by 

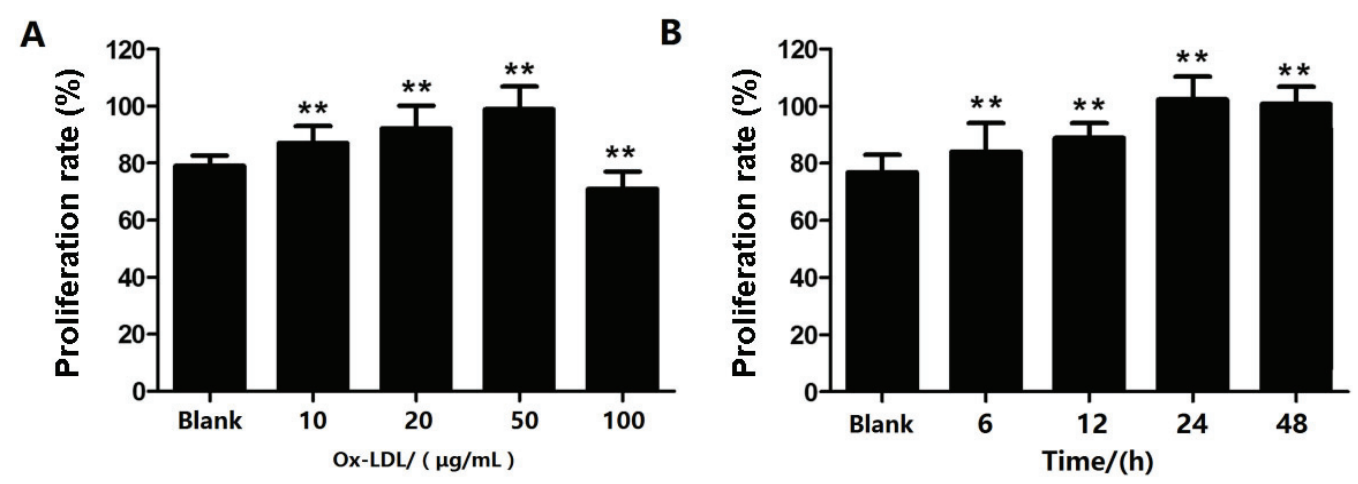

Fig. 1: The effect of ox-LDL on the VSMCs proliferation

Note: A: The effect of different concentrations ox-LDL on the VSMC proliferation; B: The effect of $50 \mu \mathrm{g} / \mathrm{mL} \mathrm{ox}-\mathrm{LDL}$ at different times on the VSMC proliferation. Compared with the blank control group, **p<0.01.

ox-LDL to varying degrees $(\mathrm{p}<0.01)$. And the survived rate of $0.1 \mathrm{mmol} / \mathrm{L}$ MEL treated cells was about $50 \%$. Therefore, the concentration of MEL treatment should be $0.1 \mathrm{mmol} / 1$ (fig. 2).

Flow cytometry analysis of the cell cycle shows that compared with the blank control group, the S phase and G1 phase VSMCs cells of the ox-LDL group increased significantly and the $\mathrm{G} 2$ phase cells decreased significantly $(p<0.01)$. While the $\mathrm{S}$ and $\mathrm{G} 1$ phase cells of the MEL group decreased significantly and the G2 phase cells increased significantly $(p<0.01)$. Compared with the ox-LDL group, the ox-LDL+MEL group had significantly decreased G1 and S phase cells and significantly increased G2 phase cells $(\mathrm{p}<0.01)$ (fig. 3).

The migration rate of VSMCs in ox-LDL group was significantly higher than blank control group, while the migration rate of VSMCs in MEL group was significantly lower than blank control group $(p<0.01)$. Compared with the ox-LDL group, the migration rate of VSMCs in the ox-LDL+MEL group decreased significantly $(\mathrm{p}<0.01)$ (fig. 4), indicating that Ox-LDL promotes the migration of VSMCs, while MEL can inhibit the migration of VSMCs induced by ox-LDL.

The results of immunofluorescence staining showed that there was a large amount of PCNA and $\alpha$-SMA expression in VSMCs of the ox-LDL group, which were significantly higher than the blank control group $(\mathrm{p}<0.01)$. The positive rate of PCNA and $\alpha$-SMA in MEL group was significantly lower than the control group ( $<<0.01$ ). Compared with the ox-LDL group, the positive rate of PCNA and $\alpha$-SMA in the ox-LDL+MEL group was decreased significantly $(\mathrm{p}<0.01)$ (fig. 5).

Western blot detection results were consistent with the above results. The expression of PCNA protein and $\alpha$-SMA protein in the ox-LDL group was significantly increased than the blank group. However, the expression of PCNA and $\alpha$-SMA protein in MEL group were decreased significantly $(\mathrm{p}<0.01)$. The expression of PCNA and $\alpha$-SMA protein in the ox-LDL+MEL group was significantly lower than the ox-LDL group $(\mathrm{p}<0.01)$ (fig. 6).

Western blot test results show that the expression of CyclinA and p-ERK 1/2 protein in ox-LDL group was increased significantly, while the expression of p-P21 protein decreased significantly $(\mathrm{p}<0.01)$. The results of the MEL group were the opposite, which the expression of CyclinA and p-ERK 1/2 protein was decreased significantly, and the expression of $\mathrm{p}-\mathrm{P} 21$ protein increased significantly $(p<0.01)$. The expression of CyclinA and p-ERK 1/2 protein in the ox-LDL+MEL group were decreased significantly than the ox-LDL group, while the expression of $\mathrm{p}-\mathrm{P} 21$ protein was increased significantly $(p<0.01)$ (fig. 7).

AS was the pathological and physiological basis of various cardiovascular diseases. At present, the pathogenesis of AS was not completely clear, whose pathology was complex and long, involving the interaction between various processes such as lipid metabolism disorder, inflammatory immunity, oxidative stress, cell proliferation and migration ${ }^{[4,8]}$. VSMCs play a major role in maintaining the shape and mechanical stability of blood vessels, and the abnormal proliferation and migration of VSMCs are the basis of AS pathogenesis ${ }^{[3]}$. Studies have shown that excessive proliferation and migration of VSMCs were related to ox-LDL-induced imbalance of oxidative and antioxidant balance in the body. Oxidative damage leaded to cell migration and proliferation to the intima, thickening of blood vessel walls and stenosis of the lumen, which accelerates AS Pathological progress ${ }^{[9,10]}$. Therefore, searching for targets and effective drugs to control the excessive proliferation and migration of VSMCs had become one of the important methods for 
preventing and treating AS cardiovascular diseases. Previous studies had found that MEL can affect the proliferation and migration of VSMCs, but its specific mechanism was not yet clear ${ }^{[6,7]}$. This paper believed that it may be through the intervention of VSMCs cell cycle, thereby inhibiting the proliferation and migration of VSMCs induced by ox-LDL.

After stimulating VSMCs with different concentrations ox-LDL in the study, it found that ox-LDL can significantly promote the proliferation of VSMCs within a certain range $(0-50 \mu \mathrm{g} / \mathrm{ml})$, which was consistent with the previous research results of others. Meanwhile, it found that $50 \mu \mathrm{g} / \mathrm{mL}$ ox-LDL inductions for $24 \mathrm{~h}$

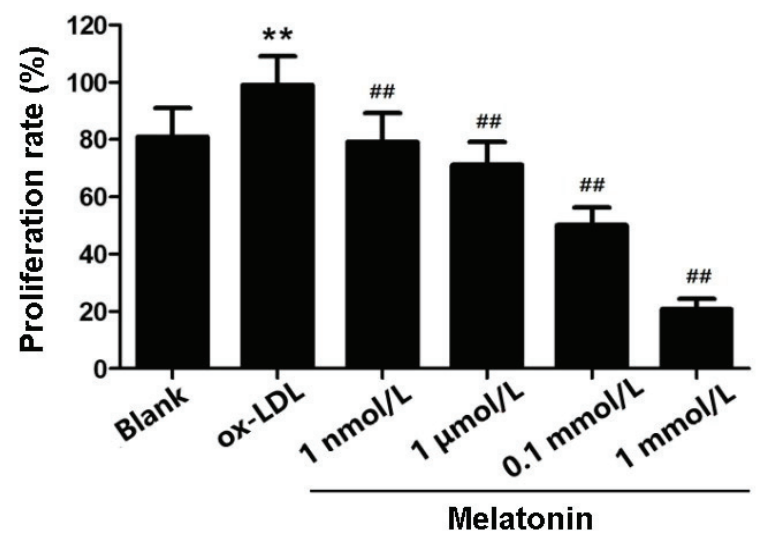

Fig. 2: The effect of MEL on the VSMCs proliferation induced by ox-LDL

Note: Compared with blank control group, $* * \mathbf{p}<0.01$; compared with ox-LDL group, ${ }^{\#} p<0.01$ can accelerate the cell cycle process and increase cell proliferation and migration by increasing the ratio of $\mathrm{S}$ phase to $\mathrm{G} 2 / \mathrm{M}$ phase and decreasing the ratio of $\mathrm{G} 0$ / G1 phase. Cell proliferation activity was an important indicator reflecting the degree of proliferation ${ }^{[11]}$. Inhibiting the cycle of VSMCs had been considered an effective strategy to control the proliferation and migration of $\mathrm{VSMCs}^{[12]}$. Therefore, the molecular mechanism of MEL's effect on VSMCs was revealed by studying the MEL effect on the proliferation and migration of VSMCs induced by ox-LDL. First, it was found that different concentrations MEL can inhibit the proliferation of VSMCs induced by oxLDL by analyzing the cell cycle by flow cytometry. And this effect was enhanced with the increase of MEL concentration, but as the MEL concentration exceeds $0.1 \mathrm{mmol} / \mathrm{L}$, the cells survival rate was significantly reduced. Under the action of $0.1 \mathrm{mmol} / 1 \mathrm{MEL}$, the ratio of $\mathrm{S}$ phase to $\mathrm{G} 2 / \mathrm{M}$ phase was reduced, and $\mathrm{G} 0 / \mathrm{G} 1$ phase can be blocked. This shown that MEL can inhibit the proliferation of VSMCs induced by ox-LDL by interfering with the cell cycle. Further branch biology research also confirmed this.

Cell proliferation was regulated by cell cycle and the cell cycle was regulated by positive and negative regulatory factors. Cyclina, a kind of cyclin, can play a positive role by regulating DNA synthesis and promoting cell mitosis ${ }^{[13]}$. p21 protein was a cyclin
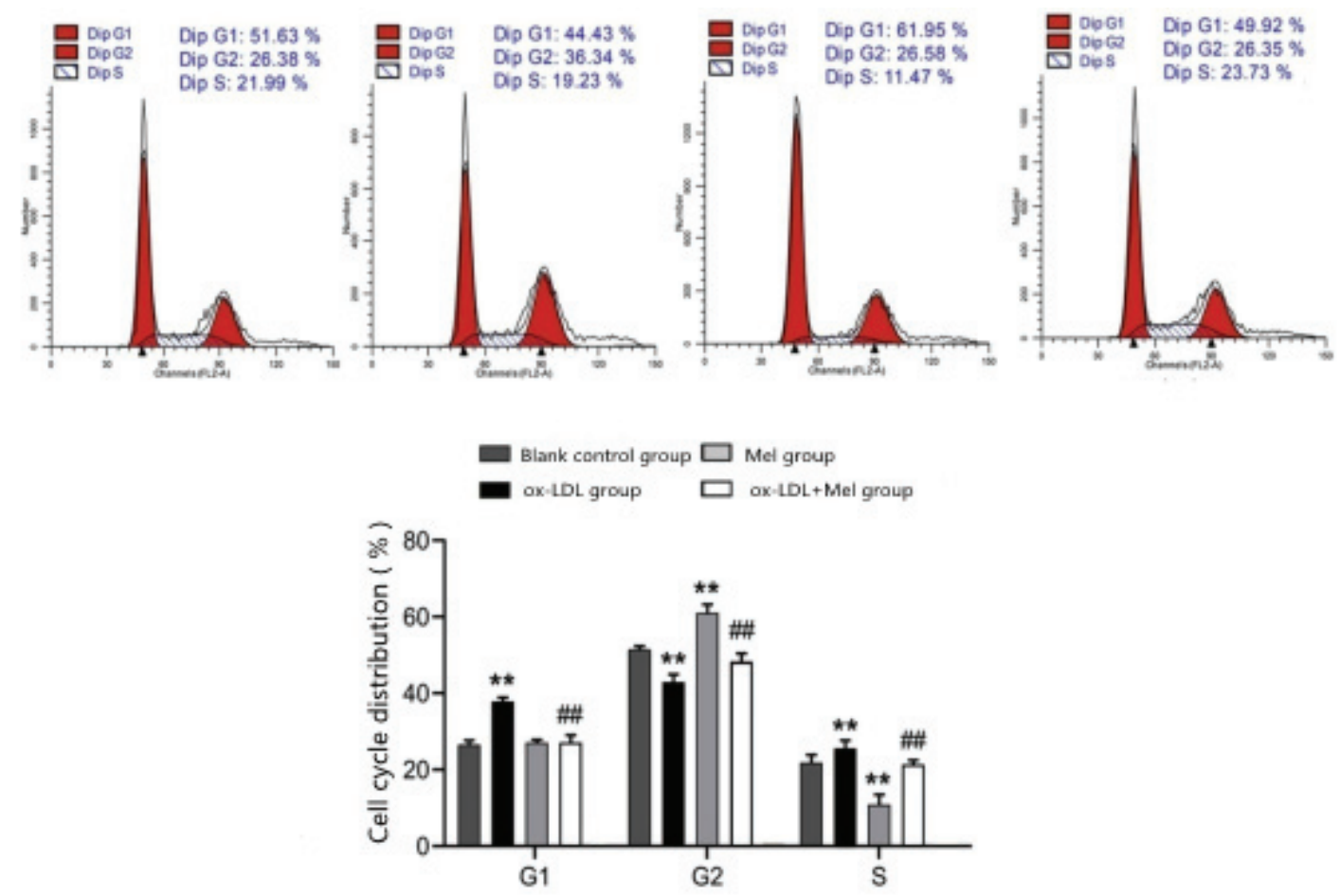

Fig. 3: Cell cycle distribution of VSMCs in each group

Note: Compared with blank control group, ${ }^{* *} \mathbf{p}<0.01$; compared with ox-LDL group, ${ }^{\# \#} \mathbf{p}<0.01$. 

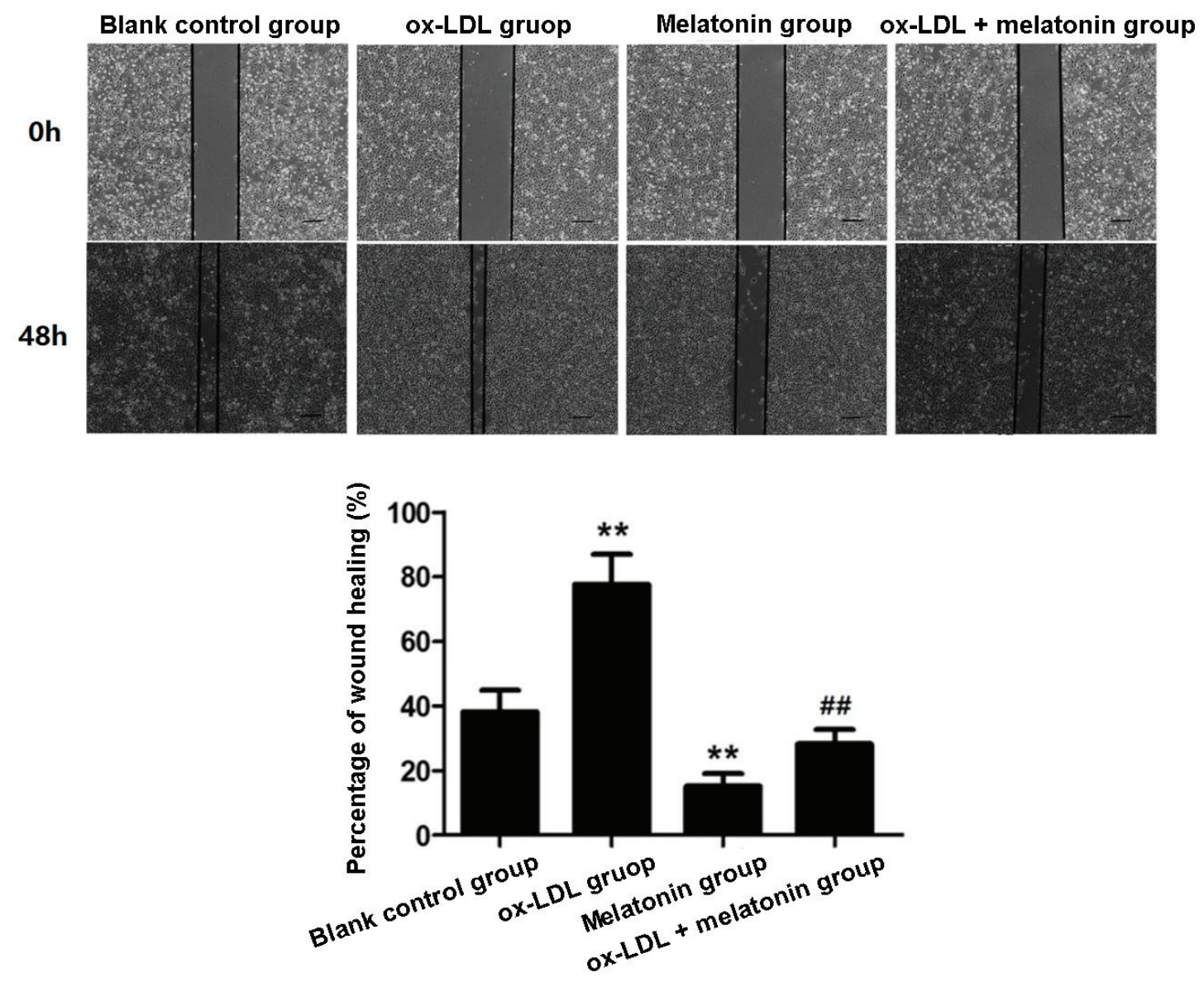

Fig. 4: VSMCs cell scratch healing in each group

Note: Compared with blank control group, ${ }^{* *} p<0.01$; compared with ox-LDL group, ${ }^{\# \#} \mathbf{p}<0.01$.

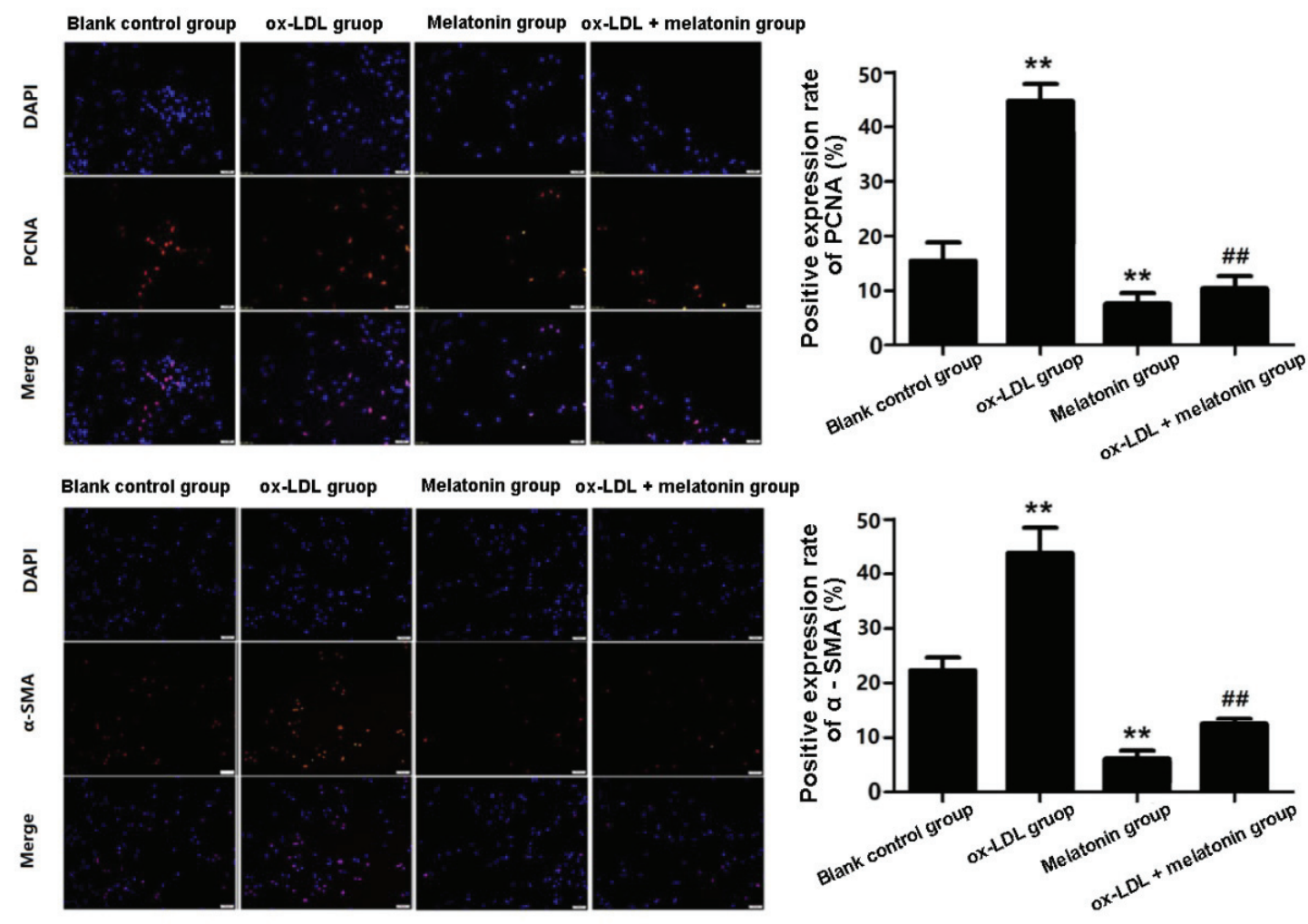

Fig. 5: PCNA and $\alpha$-SMA immunofluorescence staining $(\times 100)$ of VSMCs cells in each group Note: Compared with blank control group, ${ }^{* *} \mathbf{p}<0.01$; compared with ox-LDL group, ${ }^{\#} \mathbf{p}<0.01$. 


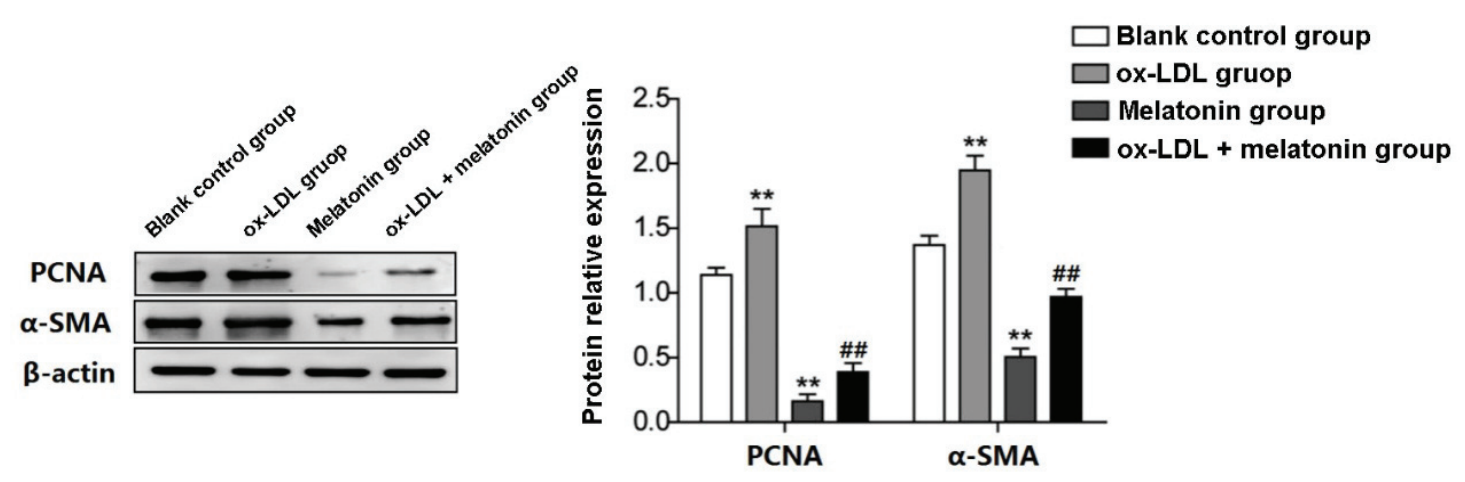

Fig. 6: Protein expression of PCNA and $\alpha$-SMA in VSMCs cells of each group

Note: Compared with blank control group, ${ }^{* *} \mathbf{p}<0.01$; compared with ox-LDL group, ${ }^{\# \#} \mathbf{p}<0.01$.

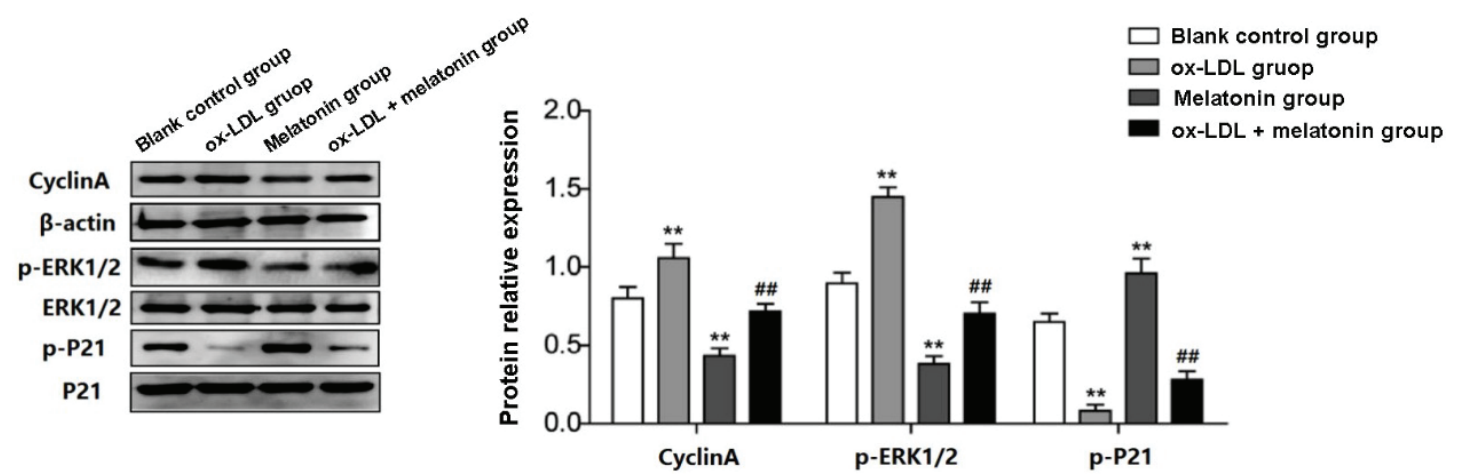

Fig. 7: CyclinA, p-ERK 1/2 and p-P21 protein expression levels of VSMCs cells in each group Note: Compared with blank control group, ${ }^{* *} \mathbf{p}<0.01$; compared with ox-LDL group, ${ }^{\#} \mathbf{p}<0.01$.

dependent kinase inhibitor (CDK), which can inhibit the cell cycle by activating the cell cycle checkpoint, thus playing a negative regulatory role ${ }^{[14]}$. In our study, Western blot analysis showed that MEL could regulate the cell cycle of VSMCs by up regulating p21 expression and inhibiting Cyclina protein. Proliferating cell nuclear antigen (PCNA) was a marker reflecting cell proliferation, and its expression level can reflect cell proliferation activity ${ }^{[15]}$. $\alpha$-smooth muscle actin ( $\alpha$-SMA) was a marker of smooth muscle, which was often used to reflect the changes of VSMCs quantity and contractility ${ }^{[16]}$. In this paper, the MEL effect on the expression of PCNA and $\alpha$-SMA in VSMCs induced by ox LDL by immunofluorescence staining and Western blot respectively was observed. The results showed that MEL could significantly inhibit the expression of PCNA and $\alpha$-SMA in VSMCs induced by ox LDL. The results of these molecular biomarkers further revealed the MEL effect on the cell cycle of VSMCs, which inhibited the proliferation of VSMCs by regulating the cell cycle of VSMCs.

In addition to studying the MEL effect on the proliferation of VSMCs, it also found that the migration rate of VSMCs (after ox-LDL treatment) was significantly higher than the control group through cell scratch test results in the study. The addition of
MEL significantly inhibited the migration of VSMCs promoted by ox-LDL. It is confirmed that MEL had the effect of inhibiting the migration of VSMCs.

Extracellular regulatory protein kinase $1 / 2$ (ERK 1/2), the subfamily of MAPKs, was the key to transmitting signals from surface receptors to the nucleus, producing biological effects. Phosphorylation-activated ERK1/2 was translocated from the cytoplasm into the nucleus. Furthermore, it mediates the transcriptional activation of Elk-1, ATF, Ap-1, c-fos and c-Jun participating in various biological reactions such as cell proliferation and differentiation, cell morphology maintenance and apoptosis. Previous studies had confirmed that activation of the ERK signaling pathway can promote the proliferation of aortic smooth muscle cells ${ }^{[17]}$. MEL was used to interfere with ox-LDL-induced proliferation of VSMCs in this study. Western blot analysis was used to observe changes in the ERK $1 / 2$ signaling pathway. The results showed that ox-LDL could induce ERK $1 / 2$ protein phosphorylation, thereby initiating the proliferation of VSMCs. After the intervention with MEL, the process could be significantly inhibited. This result suggests that MEL's inhibition of VSMCs proliferation was related to its specific blocking of ERK $1 / 2$ signaling pathway. 
In summary, MEL has the effect of inhibiting the proliferation and migration of VSMCs. The mechanism may be to reduce the expression of ERK $1 / 2$ by inhibiting the ERK $1 / 2$ signaling pathway, thereby regulating the expression of PCNA, $\alpha$-SMA, CyclinA protein and p21 protein, regulating the cell cycle of VSMCs, and inhibiting the excessive proliferation and migration of VSMCs. The results of this study provide new ideas and experimental basis for exploring the pathogenesis of AS and drug targets.

\section{Acknowledgements:}

This paper was supported by Clinical Scientific Research Project of Xinqiao Hospital [grant number 2015YLC07 to Jun Jin]; Military special grant [grant number 16BJZ37 to Jun Jin].

\section{Conflict of interests:}

The authors declared no conflicts of interest.

\section{REFERENCES}

1. Parma L, Peters HA, Baganha F, Sluimer JC, Vries MR, Quax PH. Prolonged hyperoxygenation treatment improves vein graft patency and decreases macrophage content in atherosclerotic lesions in ApoE3* leiden mice. Cells 2020;9(2):336.

2. Heikal L, Ghezzi P, Ferns G. Measuring the dynamics of hypoxia inducible factor (HIF)-1 release as a potential biomarker of hypoxia in injury models. Atherosclerosis 2018;275:e126.

3. Neggazi S, Hamlat N, Canaple L, Gauthier K, Samarut J, Bricca $\mathrm{G}$, et al. TR $\alpha$ inhibits arterial renin-angiotensin system expression and prevents cholesterol accumulation in vascular smooth muscle cells. Ann Endocrinol 2019;80(2):89-95.

4. Yuan S, Liao SC, Wang DX. Research progress on the relationship between vascular smooth muscle cells and atherosclerosis. J Pract Cardio Cerebrovasc Dis 2018;26:6-8.

5. Zhang Q, Xu L. Pathogenesis and detection of ox LDL in atherosclerosis. Int J Lab Med 2018;39:2432-6.

6. Baltatu OC, Amaral FG, Campos LA, Cipolla-Neto J.
MELatonin, mitochondria and hypertension. Cell Mol Life Sci 2017;74(21):3955-64.

7. Zhao T, Zhang H, Jin C, Qiu F, Wu Y, Shi L. MELatonin mediates vasodilation through both direct and indirect activation of $\mathrm{BKCa}$ channels. J Molecular Endocrinol 2017;59(3):219-33.

8. Zhang Y, Liu NM, Wang Y, Youn JY, Cai H. Endothelial cell calpain as a critical modulator of angiogenesis. Biochim Biophys Acta 2017;1863(6):1326-35.

9. Lei LL, Bei JJ. Research progress and treatment strategy of angiogenesis in atherosclerotic plaque. Adv Cardiol 2019;40:478-82.

10. Cornelissen A, Guo L, Sakamoto A, Virmani R, Finn AV. New insights into the role of iron in inflammation and atherosclerosis. EBioMedicine 2019;47:598-606.

11. Kwon H, Lee JJ, Lee JH, Cho WK, Gu MJ, Lee KJ, et al. Cinnamon and its components suppress vascular smooth muscle cell proliferation by up-regulating cyclin-dependent kinase inhibitors. Am J Chin Med 2015;43(04):621-36.

12. Zhan XL, Yang XH, Gu YH, Guo LL, Jin HM. Epigallocatechin gallate protects against homocysteine-induced vascular smooth muscle cell proliferation. Mol Cell Biochem 2018;439(1):13140.

13. Elkady AI, Hussein RA, Abu-Zinadah OA. Differential control of growth, apoptotic activity and gene expression in human colon cancer cells by extracts derived from medicinal herbs, Rhazya stricta and Zingiber officinale and their combination. World J Gastroenterol 2014;20(41):15275-88.

14. Li T, Wang F, Dang Y, Dong J, Zhang Y, Zhang C, et al. P21 and $\mathrm{P} 27$ promote tumorigenesis and progression via cell cycle acceleration in seminal vesicles of TRAMP mice. Int J Biol Sci 2019;15(10):2198.

15. Cardano M, Tribioli C, Prosperi E. Targeting proliferating cell nuclear antigen (PCNA) as an effective strategy to inhibit tumor cell proliferation. Curr Cancer Drug Target 2020;20(4):240-52.

16. Shinde AV, Humeres C, Frangogiannis NG. The role of $\alpha$-smooth muscle actin in fibroblast-mediated matrix contraction and remodeling. Biochim Biophys Acta 2017;1863(1):298-309.

17. Yu S, Chen Y, Chen S, Ye N, Li Y, Sun Y. Klotho inhibits proliferation and migration of angiotensin II-induced vascular smooth muscle cells (VSMCs) by modulating NF- $\kappa \mathrm{B}$ p65, Akt, and extracellular signal regulated kinase (ERK) signaling activities. Med Sci Mon Int Med J Exp Clin Res 2018;24:485160 . 